\title{
PENGOBATAN ANTI KANKER PAYUDARA TERBARU DARI EKSTRAK DAUN SINGKONG KARET (Manihot glazovii) BERBASIS TEKNOLOGI NANOPARTIKEL EMAS
}

\author{
Tri Senja Aprilia ${ }^{1}$, Sirikit Wangi Sarindang², Prima Aulia Putra ${ }^{3}$, Bambang Hernawan \\ Nugroho ${ }^{4}$ \\ ${ }_{1,2,3,4}$ Prodi Farmasi, Fakultas Matematika dan IImu Pengetahuan Alam, Universitas Islam \\ Indonesia \\ Yogyakarta
}

\begin{abstract}
ABSTRAK
Nanopartikel emas banyak digunakan dalam bidang kesehatan sebagai, biosensor, terapi kanker, antimikroba, dan dalam sistem penghantaran obat. Kandungan flavonoid berupa rutin dalam daun singkong karet (Manihot glazovii) memiliki peran sebagai bioreduktor, penstabil dalam sintesis nanopartikel emas. Penelitian ini bertujuan untuk mengetahui preparasi, karakterisasi, dan aktivitas anti kanker nanopartikel emas dari ekstrak daun singkong karet dengan biosintesis high energy. Nanopartikel emas dibuat dengan mencampurkan $\mathrm{HAuCl}_{4}$ (Asam Kloroaurat) dengan ekstrak menggunakan ultrasonik. Karakterisasi nanopartikel emas meliputi observasi visual nanopartikel emas, waktu pembentukan nanopartikel emas menggunakan spektrofotometer UV-VIS, ukuran partikel menggunakan particle size analyzer, profil gugus fungsional menggunakan Fourier Transform Infrared (FTIR), morfologi menggunakan SEM dan TEM, serta uji aktivitas antikanker menggunakan MTT Assay pada sel kanker payudara (T47D). Hasil dari penelitian ini menunjukkan bahwa formula terbaik dengan biosintesis high energy adalah formulasi dengan perbandingan ekstrak $5 \% 1000 \mathrm{ul}: \mathrm{HAuCl}_{4} 375 \mathrm{ul}$. Formula tersebut mengalami perubahan warna dari kuning menjadi merah muda, memiliki panjang gelombang $540 \mathrm{~nm}$, ukuran partikel rata-rata $65 \mathrm{~nm}$, dengan nilai PDI 0,44, memiliki morfologi segitiga, heksagon, dan lingkaran, serta memiliki aktivitas anti-kanker pada sel kanker T47D dengan mengggunakan MTT Assay. Kesimpulan: Nanopartikel emas terbentuk dari ekstrak daun singkong karet (ekstrak 5\% 1000ul: asam Chloroauric 375 ul) dan terbukti memiliki aktivitas anti kanker payudara.
\end{abstract}

Kata kunci; Nanopartikel emas, biosintesis high energy, antikanker payudara.

\section{PENDAHULUAN}

Perkembangan teknologi terkini dalam bidang farmasetis ialah pengembangan dalam sediaan nanoteknologi. Dilihat dari manfaat dan kegunaannya, nanteknologi mampu menarik banyak perhatian dari para peneliti dan ilmuwan untuk mengembangkan sediaan dalam bentuk nanoteknologi (Martien R, et al., 2016). Obat yang dirancang dengan sistem peghantaran nanopartikel memiliki keunggulan dibandingkan dengan obat yang dirancang dengan sistem konvensional (Kulkarni N, 2014). Nanopartikel yang banyak dikembangkan saat ini adalah berupa nanopartikel logam, polimer dan snedds. Nanopartikel logam paling banyak diteliti karena kemudahannya untuk disintesis dan aplikasinya yang luas sebagai obatobatan, detektor, katalis, zat pelapis permukaan, dan antibakteri. Kini penelitian tentang nanopartikel telah banyak berfokus pada sintesis menggunkan emas (Fatimah EN, et al., 2012). Nanopartikel emas banyak dimanfaatkan dalam bidang kesehatan sebagai DNA labeling, biosensor, terapi kanker, antimikrobial dan bentuk 
pengembangan dari sistem penghantaran obat (Annamalai A., et al., 2013).

Kanker adalah penyakit dengan ciri gangguan atau kegagalan mekanisme pengatur multipikasi dan fungsi homeostasis lainnya pada organisme multiseluler (Farmakologi dan Terapi, 2007). Sel kanker memiliki kemampuan mengatur sinyal perkembangan sendiri sehingga terjadi pertumbuhan dan proliferasi sel yang tidak terkendali (Hejmadi, et al., 2012). Di Indonesia, penyakit kanker payudara menempati urutan pertama dengan jumlah 39, 831 kasus (GLOBOCAN, 2008). Kanker payudara adalah tumor ganas yang berasal dari kelenjar payudara. Termasuk saluran kelenjar air susu dan jaringan penunjangnya yang tumbuh infiltratif, destruktif, serta dapat bermetastase (Suryana, 2008).

Pemanfaatan tanaman menjadi pilihan yang paling banyak digunakan dalam biosintesis metalik nanopartikel karena ramah lingkungan, mudah tersedia, dan langkah pemurnian yang mudah (Sahu N, et al., 2016). Biosintesis emas telah banyak digunakan dari berbagai macam tanaman selain itu kandungan senyawa dalam tanaman dapat menjadi agen pereduksi dalam proses sintesis nanopartikel emas. Salah satu senyawa yang dapat digunakan sebagai agen pereduksi dalam sintesis nanopartikel emas yaitu senyawa flavanoid. Daun singkong karet (Manihot glazovii) memiliki kandungan senyawa flavonoid berupa rutin (Araújo KCF, et al., 2013). Kandungan flavonoid berupa rutin yang terkandung dalam daun singkong memiliki peran sebagai agen pereduksi dan stabilisator dalam sintesis nenopartikel emas (Warditiani NK, et al, 2015). Daun singkong mengandung senyawa vitamin C, flavonoid, triterpenoid, tanin dan saponin (Meilawaty Z, 2013).

Pada penelitian sebelumnya yaitu preparasi dan karakterisasi nanopartikel emas ekstrak daun singkong karet menggunakan biosintesis low energy, hasil yang didapat yaitu memiliki ukuran 50-115 nm, dengan waktu yang cukup lama dalam pembentukan nanopartikel emas (Faradita, 2017). Pada penelitian ini dilakukan preparasi nanopartikel emas dengan ekstrak daun singkong karet 5\% dengan proses biosintesis high energy. Nanopartikel emas dibentuk dengan menggunakan metode biosintesis high energy, yaitu ekstrak daun singkong karet $5 \%$ sebagai agen pereduksi dan agen stabilisator, kemudian diultrasonic selama 2 menit. Penggunaan ultrasonik dapat mempersingkat waktu pembentukan nanopartikel emas, dan mampu mengontrol bentuk, ukuran partikel yang dihasilkan. Kualitas nanopartikel emas dapat diketahui dengan melakukan karakterisasi.

\section{METODE PENELITIAN Alat, Bahan dan Metode}

Alat yang digunakan pada penelitian ini adalah alumunium foil, atomic absorbtion spectroscopy (Perkin Elmer 5100 PC), batang pengaduk, bluetip, fourier transform infrared (FTIR) (Thermo Nicolet Avatar 360), heater, kertas saring, lemari asam, mikropipet (Thermoscientific Finnpipette), oven, particle size analyzer (Horiba Scientific, Nano Particle Analyzer SZ-100), pipet tetes, scanning electron microscrope (PRO X), seperangkat alat gelas, spektofotometer UV-vis (Hitachi), timbangan analitik (Metler Toledo XS205 Dual Range), transmission electron microscopy (JEOL JEM-1010), Ultrasonic. Bahan yang digunakan pada penelitian kali ini adalah aqua pro injection, Chloaric acid, dan Daun Singkong Karet (Manihot glazovii), Sel Kanker Payudara (T47D). Dilakukan pengujian kandungan emas (Au) dalam $\mathrm{HAuCl}_{4}$ menggunakan AAS, pembuatan nanopartikel emas, karakterisasi nanopartikel emas meliputi observasi visual nanopartikel emas, waktu pembentukan nanopartikel emas, ukuran partikel, morfologi dan profil gugus fungsional, serta uji aktivitas antikanker payudara.

\section{HASIL DAN PEMBAHASAN Kandungan Emas dalam Asam Kloroaurat}

Pembuatan asam kloroaurat (HAuCl4) 0,5 mM yang telah di buat dari 
campuran aquaregia, emas murni 0,0493 gram dan aqua pro injection kemudian dianalisis dengan menggunakan spektroskopi serapan atom. Jumlah emas pada larutan asam kloroaurat yang dihasilkan kemudian dianalisis dengan parameter $\mathrm{Au}$ dan didapatkan jumlah Au sebesar 0,5 mM

\section{Pembuatan Nanopartikel Emas}

Nanopartikel emas dibuat dengan cara mencampurkan larutan $\mathrm{HAuCl}_{4}$ dengan larutan ekstrak daun singkong karet $5 \%$ sebagai agen bioreduktor yang dimasukan kedalam microtube. Diambil dengan micro pipet asam kloroaurat 0,5 $\mathrm{mM}$ sebanyak $225 \mathrm{uL}$ sampai $450 \mathrm{uL}$ dengan interval antar formula sebanyak $25 \mathrm{uL}$, kemudian dimasukan ke dalam microtube yang sudah terisi $1000 \mathrm{ul}$ ekstrak daun singkong karet $5 \%$, sesuai pada Tabel 1 kemudian diultrasonic selama 2 menit.

Tabel 1. Formulasi Nanopartikel Emas

\begin{tabular}{llll}
\hline Formula & Konsentrasi & $\begin{array}{l}\text { Ekstrak } \\
\text { Singkong Karet (ul) }\end{array}$ & $\begin{array}{c}\text { Daun } \\
\text { HAuCL }_{4}(\mathbf{u l})\end{array}$ \\
\hline F1 & $5 \%$ & 1000 & 225 \\
\hline F2 & $5 \%$ & 1000 & 250 \\
\hline F3 & $5 \%$ & 1000 & 275 \\
\hline F4 & $5 \%$ & 1000 & 300 \\
\hline F6 & $5 \%$ & 1000 & 325 \\
\hline F7 & $5 \%$ & 1000 & 350 \\
\hline F8 & $5 \%$ & 1000 & 375 \\
\hline F9 & $5 \%$ & 1000 & 400 \\
\hline F10 & $5 \%$ & 1000 & 425 \\
\hline
\end{tabular}

\section{Karakterisasi Nanopartikel Emas \\ Observasi Visual Nanopartikel}

Pengamatan perubahan warna pada nanopartikel emas dilakukan dengan mengamati perubahan warna nanopartikel emas. Pengamatan perubahan warna atau visual bersifat kualitatif untuk melihat proses pembentukan nanopartikel emas. Pengamatan dilakukan untuk melihat perubahan warna yang terjadi sebelum ekstrak ditambahkan dan setelah ekstrak ditambahkan kedalam larutan $\mathrm{HAuCl}_{4}$ 0,5 $\mathrm{mM}$. Pembentukan nanopartikel emas ditandai dengan perubahan warna pada sampel yang semula berwarna kuning bening menjadi warna merah muda hingga ungu pada rentang waktu tertentu. (Gambar 1, 2).

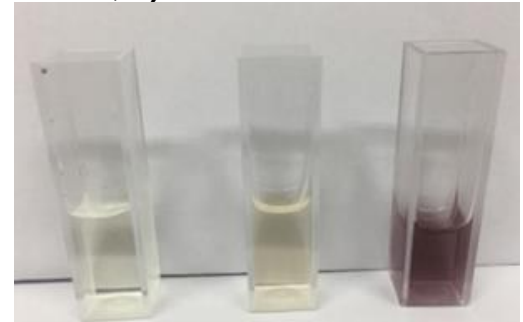

Gambar 1. Perubahan Warna sebelum Nanopartikel Emas (dari kiri ke kanan $\mathrm{HAuCl}_{4}$, ekstrak daun singkong karet $5 \%$, ekstrak daun singkong karet $5 \% 1000$ ul dengan $375 \mathrm{ul} \mathrm{HAuCl}_{4}$ )

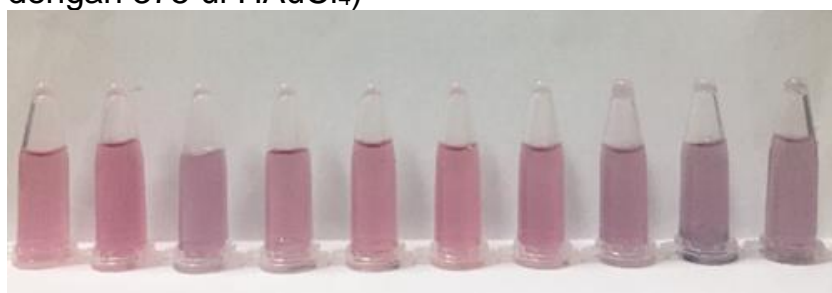

Gambar 2. Visual Warna pada Jam ke 0

Ekstrak Daun Singkong Karet 5\% dari

Formula 1 (225 ul $\mathrm{HAuCl}_{4}$ ) sampai

Formula 10 Ekstrak 5\% (450 ul $\mathrm{HAuCl}_{4}$ ). Pada jam ke 0 sampai jam ke 1,pada ekstrak daun singkong karet $5 \%$ dari formula 1 (225 ul $\mathrm{HAuCl}_{4}$ ) sampai formula 10 ekstrak 5\% (450 ul $\mathrm{HAuCl}_{4}$ ) mengalami perubahan warna menjadi merah muda keunguan secara langsung setelah dilakukan ultrasonic. Hasil yang didapat menunjukan bahwa konsentrasi ekstrak daun singkong karet berpengaruh terhadap waktu yang dibutuhkan untuk terjadi nya perubahan warna nanopartikel emas, semakin tinggi konsentrasi ekstrak yang digunakan maka waktu yang dibutuhkan untuk terjadinya perubahan warna nanopartikel emas semakin lama. Selain itu volume penambahan $\mathrm{HAuCl}_{4}$ 
juga berpengaruh terhadap waktu perubahan warna nanopartikel emas, semakin kecil konsentrasi asam kloroaurat yang ditambahkan maka waktu yang dibutuhkan semakin kecil, sedangkan konsentrasi asam kloroaurat yang ditambahkan semakin besar maka waktu yang dibutuhkan lebih besar.

\section{Observasi Panjang Gelombang} menggunakan Spektrofotometer Uv-

Vis.

Pengaruh waktu kontak terhadap kestabilan nanopartikel emas dapat diamati melalui panjang gelombang maksimum dan absorbansi.

Spektrofotometer UV-Vis digunakan untuk mengonfirmasi terbentuknya nanopartikel. Dimulai dengan mengukur panjang gelombang maksimal dari ektrak daun singkong karet, panjang gelombang tersebut menjadi acuan atau monitoring pembentukan nanopartikel emas. Panjang gelombang nanopartikel emas berada pada range 500-550 nm. Panjang gelombang serapan yang didapat pada jam ke 0 dan jam ke 24 dapat dilihat pada Tabel 2.

Tabel 2. Hasil Analisis Spektrofotometer UV-Vis Jam ke 0 dan 24

\begin{tabular}{|c|c|c|c|c|}
\hline \multirow{3}{*}{ Formula } & \multirow{3}{*}{$\begin{array}{l}\text { Konsentrasi } \\
\text { Ekstrak }\end{array}$} & \multirow{3}{*}{$\begin{array}{l}\text { Konsentrasi } \\
\mathrm{HAuCl}_{4}(\mu \mathrm{L})\end{array}$} & \multicolumn{2}{|c|}{ Waktu } \\
\hline & & & 0 jam & 24 jam \\
\hline & & & $\begin{array}{c}\text { Panjang } \\
\text { gelombang }(\mathrm{nm})\end{array}$ & $\begin{array}{c}\text { Panjang gelombang } \\
(\mathrm{nm})\end{array}$ \\
\hline 1 & $5 \%$ & 225 & 486 & 542 \\
\hline 2 & $5 \%$ & 250 & 490 & 544 \\
\hline 3 & $5 \%$ & 275 & 492 & 546 \\
\hline 4 & $5 \%$ & 300 & 414 & 498 \\
\hline 5 & $5 \%$ & 325 & 490 & 498 \\
\hline 6 & $5 \%$ & 350 & 492 & 496 \\
\hline 7 & $5 \%$ & 375 & 492 & 540 \\
\hline 8 & $5 \%$ & 400 & 440 & 542 \\
\hline 9 & $5 \%$ & 425 & 418 & 544 \\
\hline 10 & $5 \%$ & 450 & 414 & 544 \\
\hline
\end{tabular}

Hasil yang didapat dari

Spektrofotometer UV-Vis pada penelitian ini menunjukan pada jam ke 0 , dengan konsentrasi ekstrak daun singkong karet $5 \%$ formula 1 sampai 10 didapatkan nilai panjang gelombang 414-490 nm. Pada jam ke 24 terjadi pergeseran batokromik dari panjang gelombang konsentrasi $5 \%$, didapatkan nilai panjang gelombang dalam rentang 540-542 $\mathrm{nm}$.

Dari data tersebut menunjukan bahwa beberapa formula masih berada dalam nilai panjang gelombang nanopartikel emas dengan nilai panjang gelombang $500-550 \mathrm{~nm}$, yaitu pada konsentrasi ekstrak 5\% formula 1 (225 ul $\mathrm{HAuCl}_{4}$ ), formula 2 (250 ul $\mathrm{HAuCl}_{4}$ ), formula 3 (275 ul HAuCl 4 ), formula 7 (375 ul $\mathrm{HAuCl}_{4}$ ), formula 8 (400 ul $\mathrm{HAuCl}_{4}$ ), formula 9 (425 ul $\left.\mathrm{HAuCl}_{4}\right)$, formula 10
(450 ul $\mathrm{HAuCl}_{4}$ ), Berdasarkan data perubahan panjang gelombang maka dapat disimpukan bahwa pembentukan nanopartikel emas terbentuk pada ke 24 berkisar pada panjang gelombang 540$546 \mathrm{~nm}$. Hasil ini juga dapat mendukung data sebelumnya yaitu pada uji perubahan warna yang semula berwarna kuning bening menjadi merah muda hingga ungu.

Karakterisasi Ukuran Nnopartikel emas dengan Particle Size Analyzer (PSA).

Penentuan ukuran partikel nanopartikel emas dilakukan dengan menggunakan alat particle size analyzer (Horiba Scientific, Nano Particle Analyzer SZ-100) sebanyak tiga kali replikasi. Pengukuran ukuran globul dan indeks polidispersitas hanya dilakukan pada sampel yang memiliki panjang 
gelombang $500 \mathrm{~nm}$ - $550 \mathrm{~nm}$ (termasuk dalam range nanopartikel emas). Nilai ukuran globul dan indeks polidispersitas nanopartikel sampel dapat dilihat pada Tabel 3. Hasil yang didapat menunjukkan bahwa sampel nanopartikel emas ekstrak daun singkong karet termasuk ke dalam range nilai ukuran partikel yang baik untuk nanopartikel emas yaitu $10 \mathrm{~nm}$ $100 \mathrm{~nm}$, serta nilai PI yang baik, yaitu < 0,7 .

Tabel 3. Hasil Pengukuran Ukuran Partikel 7 Formula

\begin{tabular}{|c|c|c|c|c|c|c|c|}
\hline $\mathbf{F}$ & Kons. & $\begin{array}{l}\text { V.Eks } \\
\text { (ul) }\end{array}$ & $\begin{array}{c}\mathrm{V} . \\
\mathrm{HAuCl} \\
\text { (ul) }\end{array}$ & $\begin{array}{c}\lambda \text { Jam ke } \\
0(\mathrm{~nm})\end{array}$ & $\begin{array}{c}\lambda \text { Jam ke } \\
24 \\
(\mathrm{~nm})\end{array}$ & $\begin{array}{c}\text { Ukuran } \\
\text { partikel } \\
(\mathrm{nm}) \\
(\overline{\mathbf{x}} \pm \mathrm{SD})\end{array}$ & $\begin{array}{l}\text { PDI (Đ) }(\bar{x} \\
\pm \text { SD) }\end{array}$ \\
\hline 1 & $5 \%$ & 1000 & 225 & 486 & 542 & $\begin{array}{c}110.33 \pm \\
19.71\end{array}$ & $\begin{array}{c}0.63 \pm \\
0.004\end{array}$ \\
\hline 2 & $5 \%$ & 1000 & 250 & 490 & 544 & $\begin{array}{c}233.65 \pm \\
141.06\end{array}$ & $1.20 \pm 0.75$ \\
\hline 3 & $5 \%$ & 1000 & 275 & 492 & 546 & n.d & n.d \\
\hline 7 & $5 \%$ & 1000 & 375 & 492 & 540 & $\begin{array}{c}65.30 \pm \\
0.17\end{array}$ & $0.44 \pm 0.05$ \\
\hline 8 & $5 \%$ & 1000 & 400 & 440 & 542 & $\begin{array}{c}94.23 \pm \\
2.85\end{array}$ & $\begin{array}{c}0.56 \pm \\
0.006\end{array}$ \\
\hline 9 & $5 \%$ & 1000 & 425 & 418 & 544 & $99.3 \pm 0$ & $0.48 \pm 0$ \\
\hline 10 & $5 \%$ & 1000 & 400 & 414 & 544 & $\begin{array}{c}110.6 \pm \\
19.23\end{array}$ & $0.58 \pm 0.03$ \\
\hline
\end{tabular}

Keterangan :

$\begin{array}{llll}\mathrm{F} & \text { : Formula } & \text { V. Eks } & \text { : Volume ekstrak }\end{array}$

Kons : Konsentrasi ekstrak V. $\mathrm{HauCl}_{4}$ : Volume Asam Kloroaurat

Pada konsentrasi ekstrak daun singkong karet $5 \%$ formula 7 nanopartikel dengan jumlah emas 375 ul menghasilkan ukuran partikel terkecil (Lampiran 1,2,3) yaitu dengan nilai ukuran partikel $65.30 \pm$ 0.17 dan indeks polidispersitas $0.44 \pm$ 0.05 hasil yang didapat telah masuk kedalam nilai ukuran partikel yang baik untuk nanopartikel emas yaitu 1-200 nm, sedangkan untuk nilai indeks polidispersitas mendapatkan hasil $<0,7$ yaitu $0.44 \pm 0.05$.

\section{Karakterisasi Gugus Fungsi}

Nanopartikel Emas menggunakan FTIR

Penentuan gugus fungsi dari ekstrak daun singkong karet dilakukan pengukuran menggunakan alat FTIR. Yang dibaca dalam FTIR adalah formula 7 perbandingan emas dan $\mathrm{HAuCl}_{4}$ (1000ul : $375 \mathrm{ul}$ ) berdasarkan data sebelumnya.

Spektrum IR ekstrak daun singkong karet, menunjukan beberapa serapan khas untuk beberapa gugus fungsi (Lampiran 4), diantaranya pada serapan
$3452,18 \mathrm{~cm}^{-1}$ yang menunjukan adanya ikatan gugus hidroksil $\mathrm{O}-\mathrm{H}$, pada serapan $2065,61 \mathrm{~cm}^{-1}$ menunjukan adanya fenol, serapan 1635,07 $\mathrm{cm}^{-1}$ menunjukan adanya ikatan $\mathrm{C}=\mathrm{C}$ alkyne dan cincin aromatis, serta serapan $563,36 \mathrm{~cm}^{-1}$ yang menunjukan adanya gugus fosfat.

Pada spektrum IR hasil reduksi dari ekstrak daun singkong karet dengan $\mathrm{HAuCl} 4$ memperlihatkan adanya pergeseran panjang gelombang spektrum dari ekstrak daun singkong karet sebelum dan sesudah mereduksi (Lampiran 5). Pergeseran bilangan gelombang terjadi dari $3452,18 \mathrm{~cm}^{-1}$ menjadi $3450,00 \mathrm{~cm}^{-1}$ menunjukkan bahwa terjadi interaksi antara gugus $\mathrm{OH}$ dengan nanopartikel emas, Pada panjang gelombang $2073 \mathrm{~cm}^{-}$ 1 menunjukan gugus fenol, dan pada panjang gelombang $1634,55 \mathrm{~cm}^{-1}$ adanya ikatan $\mathrm{C}=\mathrm{C}$ alkena dan cincin aromatis, serta $572,60 \mathrm{~cm}^{-1}$ menunjukan adanya gugus fosfat Tabel 4. 
Tabel 4. Hasil Pembacaan Spektrum IR

\begin{tabular}{ccc}
\hline $\begin{array}{c}\text { Ekstrak Daun Singkong } \\
\text { Karet }\left(\mathbf{c m}^{-1}\right)\end{array}$ & Formula $\mathbf{7}\left(\mathbf{c m}^{-1}\right)$ & Gugus fungsi \\
3452,18 & 3450,00 & Hidroksil $(\mathrm{O}-\mathrm{H})$ \\
2065,61 & 2073,47 & Fenol \\
1635,07 & 1634,55 & Alkynes ( C=C) \\
563,36 & 572,60 & Fosfat $\left(\mathrm{PO}^{3+}\right)$ \\
\hline
\end{tabular}

Morfolgi nanopartikel emas dapat diketahui dengan Transmission Electron Microscopy (TEM) dan Scanning Electron Microscopy (SEM). Sampel yang digunakan untuk pengujian morfologi partikel nano dengan Transmission Electron Microscopy (TEM) dan Scanning Electron Microscopy (SEM) sampel dengan konsentrasi ekstrak $5 \%$ yaitu pada formula 7 dengan perbandingan ekstrak daun singkong karet dan $\mathrm{HAuCl}_{4}$ (1000ul : $375 \mathrm{ul}$ ). Sampel tersebut dipilih karena memiliki ukuran partikel terkecil dan nilai indeks polidispersitas yang paling baik
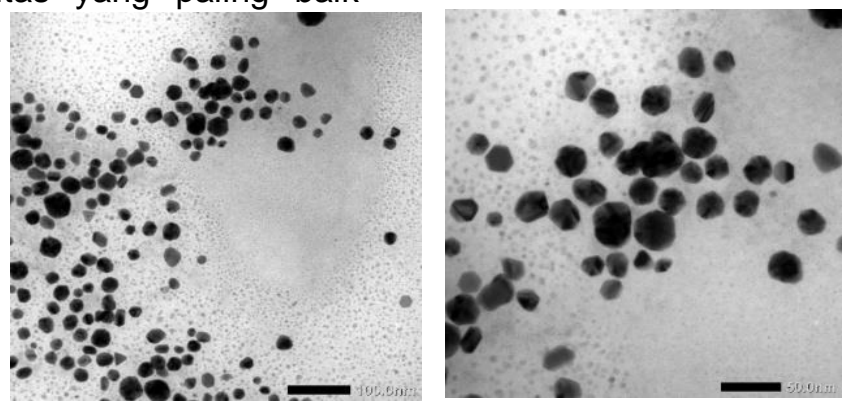

Gambar 5. Hasil Morfologi Nanopartikel Emas Menggunakan TEM

Hasil pengamatan SEM pada formula 7 menunjukkan morfologi nanopartikel pada (Gambar 6). Didapatkan hasil struktur spheris yang tidak beraturan dikarenakan nanopartikel dibandingkan dengan formula lainnya. Hasil pengamatan TEM pada formula 7 menunjukan rentang ukuran partikel yang terbentuk yaitu berada pada kisaran $41 \mathrm{~nm}$ - $71 \mathrm{~nm}$ dengan berbagai macam bentuk yaitu segitiga, segi enam dan lingkaran tidak sempurna. 

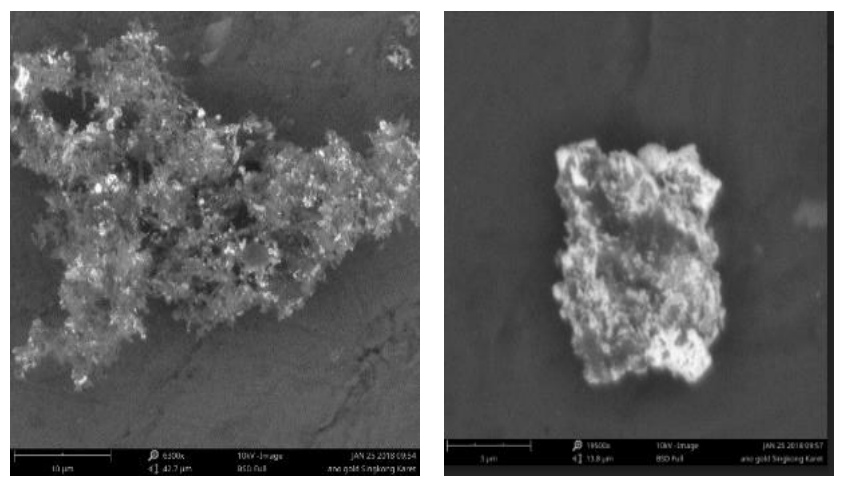

Gambar 7. Hasil Morfologi Nanopartikel Emas Menggunakan SEM

\section{Uji Aktivitas Antikanker pada Sel} Kanker T47D

Uji sitotoksik untuk melihat aktivitas antikanker dari nanopartikel emas ekstrak daun singkong karet 5\% pada formula terbaik, yaitu formula 7 dengan perbandingan ekstrak : $\mathrm{HAuCl}_{4}$ $(1000 \mu \mathrm{l}: 375 \mu \mathrm{l})$ dan juga pada ekstrak daun singkong terhadap kultur sel T47D (sel kanker payudara) dilakukan menggunakan metode MTT (microculture tetrazolium technique). Prinsip dari metode ini adalah pada sel hidup aktivitas mitokondria selalu konstan, sehingga peningkatan atau penurunan viabilitas sel berhubungan secara langsung dengan aktivitas mitokondria.

Pada penelitian ini parameter pengukuran aktivitas nanopartikel emas ekstrak daun singkong karet terhadap sel T47D ditunjukkan dengan persen viabilitas sel. Jumlah sel yang hidup setelah pemberian ekstrak dengan berbagai konsentrasi disajikan pada tabel .5

Tabel 5. Hasil Uji Sitotoksisitas Nanopartikel Emas Ekstrak Daun Singkong Karet terhadap Sel T47D dengan Metode MTT

\begin{tabular}{cc}
\hline $\begin{array}{c}\text { Konsentrasi } \\
(\%)\end{array}$ & $\begin{array}{c}\text { Viabilitas Sel HeLa } \\
(\%)\end{array}$ \\
\hline 50 & 28.967 \\
25 & 93.635 \\
12.5 & 102.214 \\
6.25 & 106.596 \\
3.125 & 106.089 \\
1.5625 & 110.517 \\
\hline
\end{tabular}

Berdasarkan data tersebut dapat diketahui bahwa terdapat hubungan antara konsentrasi ekstrak dengan persen sel hidup. Aktivitas sitotoksik meningkat dengan meningkatnya konsentrasi sediaan. Efek toksik ekstrak terhadap sel T47D ditandai dengan menurunnya persen sel hidup.

$$
\text { Aktivitas sitotoksik dapat }
$$

dinyatakan dengan nilai $\mathrm{IC}_{50}$, yaitu konsentrasi yang menyebabkan kematian pada $50 \%$ populasi sel. Perhitungan nilai
$\mathrm{IC}_{50}$ dilakukan dengan membuat persamaan regresi linier antara konsentrasi ekstrak dengan persen sel hidup. Hasil analisis data menunjukkan bahwa nanopartikel emas ekstrak daun singkong karet formula ke 7 yaitu dengan perbandingan ekstrak daun singkong karet 5\%: H AuCl4 (1000ul : 375 ul) memiliki aktivitas sitotoksik terhadap sel T47D dengan nilai $\mathrm{IC}_{50}$ sebesar 42.47329 \%. (Gambar 9). 


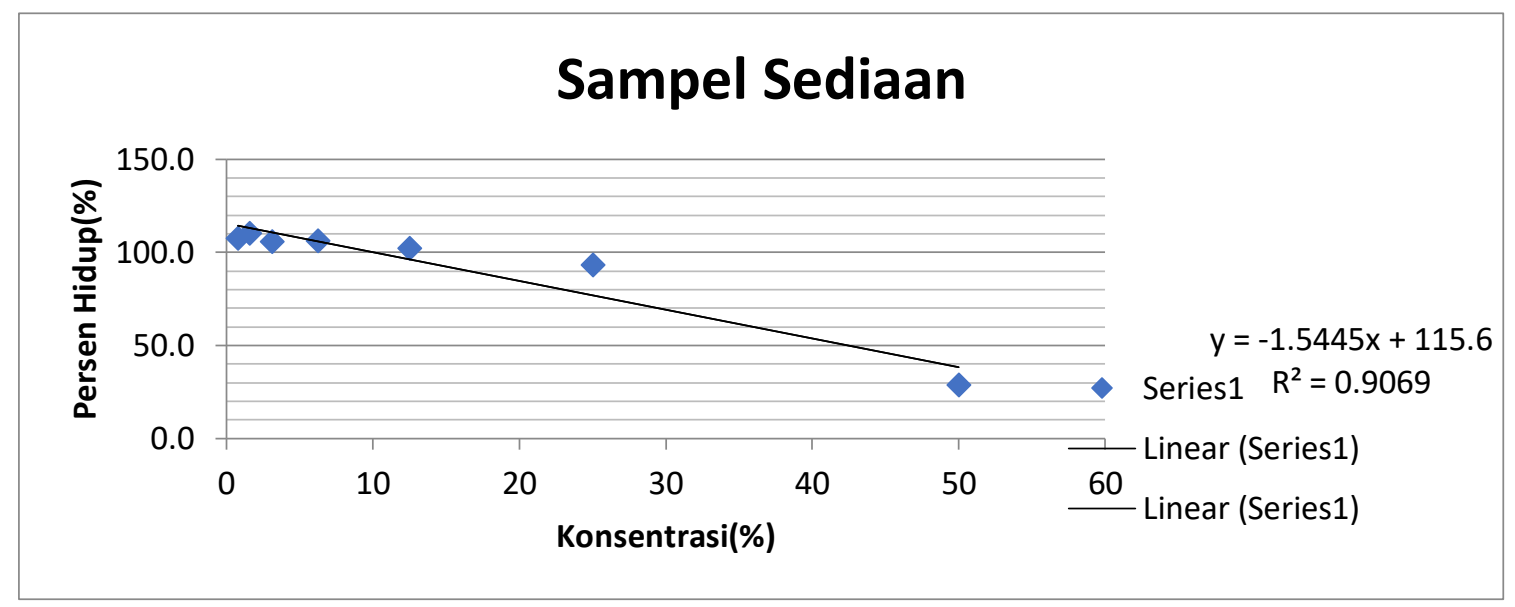

Gambar 9. Hasil IC 50 nanopartikel Emas Ekstrak Daun Singkong Karet terhadap Sel T47D dengan Metode MTT

\section{KESIMPULAN}

Dari penelitian preparasi dan karakterisasi nanopartikel emas ekstrak daun singkong karet menggunakan biosintesis high energy, dengan konsentrasi ekstrak $5 \%$ yang dibuat dalam 10 formula didapatkan satu formula terbaik yaitu formula 7 dengan perbandingan 1000ul ekstrak daun singkong karet : 375 ul $\mathrm{HAuCl}_{4}$. Karakteristik dari nanopartikel emas ekstrak daun singkong karet yang dihasilkan dengan proses biosintesis high energy, didapatkan perubahan warna kuning menjadi merah muda, memiliki panjang gelombang serapan $531 \mathrm{~nm}$, partikel $65.30 \pm 0.17$ dan indeks polidispersitas $0.44 \pm 0.05$ dan morfologi yang terbentuk yaitu segitiga, segienam dan lingkaran tidak sempurna (TEM) dan spherical (SEM). Serta terbukti memiliki aktivitas antikanker pada sel T47D (sel kanker payudara) dengan menggunakan metode MTT Assay.

\section{UCAPAN TERIMAKASIH}

Terimakasih kepada kepada Dosen Pemimbing dan Laboran Teknologi Farmasi Universitas Islam Indonesia serta seluruh pihak yang membantu dalam penyelesaian penelitian ini.

\section{DAFTAR PUSTAKA}

Annamalai A., et al., 2013. Green synthesis, characterization and antimicrobial activity of Au NPs using Euphorbia hirta L. leaf extract. Colloids Surf B Biointerfaces 9, 108, 60-5.

Araújo KCF, et al., 2013. Bioconversion of quercetin and rutin and the cytotoxicity activities of the transformed products. Food Chem Toxicol 51, 93-6.

Battista E, 2017. Metal enhanced fluorescence on super-hydrophobic clusters of gold nanoparticles. Microelectron Eng 175, 7-11.

Faradita M.A., 2017, Preparasi dan Karakterisasi Nanopartikel Emas Ekstrak Daun Singkong Karet (Manihot glazovii) Dengan Proses Biosintesis Ramah Lingkungan,. Universitas Islam Indonesia.

Farmakologi dan Terapi, 5th ed, 2007. Departemen Farmakologi dan Terapeutik Fakultas Kedokteran Universitas Indonesia, Jakarta.

Fatimah EN, et al., 2012. Sintesis dan Karakterisasi Nanopartikel Emas sebagai Material Pendukung Aktivitas Tabir Surya Turunan Sinamat. Pros. Semin. Nas. Kim. Unesa.

GLOBOCAN, 2008. European agestandardised rates calculated by Statistical Information Team at Cancer Research UK 2011 using data from GLOBOCAN. IARC 1. 
Hejmadi, et al., 2012. Introduction to Cancer Biology. Momna Hejmadi Ventus Publ.

Kulkarni N, 2014. Biosynthesis of Metal Nanoparticles: A Review. J Nanotechnol 1-8.

Martien R, et al., 2016. Perkembangan Teknologi Nanopartikel Sebagai Sistem Penghantaran Obat.

Meilawaty Z, 2013. Efek ekstrak daun singkong (Manihot utilissima) terhadap ekspresi COX-2 pada monosit yang dipapar LPS E. coli (The effect of Manihot utilissima extracts on COX-2 expression of monocytes induced by LPS E. coli).
Dent J Maj Kedokt Gigi 46, 196201.

Sahu N, et al., 2016. Synthesis of silver nanoparticles using flavonoids: hesperidin, naringin and diosmin, and their antibacterial effects and cytotoxicity. Int Nano Lett 6, 17381.

Warditiani NK, et al, 2015. Pengaruh Pemberian Ekstrak Etanol 70\% Daun Singkong (Manihot utilissima Pohl) terhadap Kadar Gula Darah Mencit Jantan Galur Balb/C yang Diinduksi Aloksan. J Farm Udayana 4. 
Lampiran 1. Hasil Pengukuran Nanopartikel emas dengan Formula 7 Particle Size Analyzer (PSA) Replikasi 1

MORIBA

\section{SZ-100}

\section{F7.2 5\%.nsz}

\section{Measurement Results}

Date

Measurement Type

Sample Name

Scattering Angle

Temperature of the Holder

Dispersion Medium Viscosity

Transmission Intensity before Meas.

Distribution Form

Distribution Form(Dispersity)

Representation of Result

Count Rate

\section{Calculation Results}

\begin{tabular}{|c|c|c|c|c|}
\hline Peak No. & S.P.Area Ratio & Mean & S. D. & Mode \\
\hline 1 & 0.05 & $5.7 \mathrm{~nm}$ & $2.3 \mathrm{~nm}$ & $6.7 \mathrm{~nm}$ \\
\hline 2 & 0.95 & $94.2 \mathrm{~nm}$ & $65.2 \mathrm{~nm}$ & $77.5 \mathrm{~nm}$ \\
\hline 3 & - & $-\mathrm{nm}$ & $-\mathrm{nm}$ & $-\mathrm{nm}$ \\
\hline Total & 1.00 & $89.4 \mathrm{~nm}$ & $66.5 \mathrm{~nm}$ & $77.5 \mathrm{~nm}$ \\
\hline
\end{tabular}

\section{Cumulant Operations}

Z-Average

PI
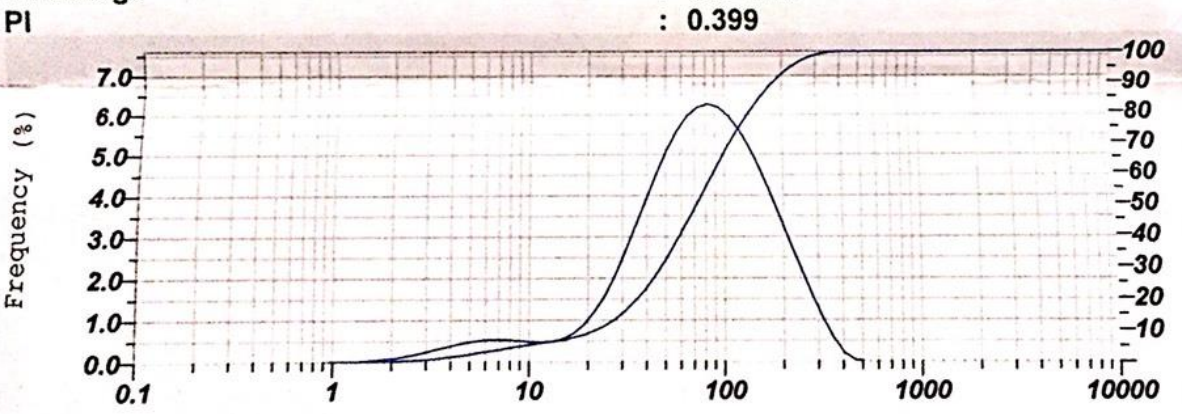

อ.

: Nanogold F7 5\%

: 18151

IStandard|

: Monodisperse

: Scattering Light Intensity

: 754 kCPS 
Lampiran 2. Hasil Pengukuran Nanopartikel emas dengan Formula 7 Particle Size Analyzer (PSA) Replikasi 2

Lampiran 3. Hasil Pengukuran Nanopartikel emas dengan Formula 7

$\underset{\text { Scientific }}{\text { HORIBA }}$

\section{SZ-100}

F7 5\%.nsz

Measurement Results

Date

Measurement Type

Sample Name

Scattering Angle

Temperature of the Holder

Dispersion Medium Viscosity

Transmission Intensity before Meas.

Distribution Form

Distribution Form(Dispersity)

Representation of Result

Count Rate

Calculation Results

\begin{tabular}{|c|c|c|c|c|}
\hline Peak No. & S.P.Area Ratio & Mean & S. D. & Mode \\
\hline 1 & 1.00 & $74.1 \mathrm{~nm}$ & $22.4 \mathrm{~nm}$ & $68.4 \mathrm{~nm}$ \\
\hline 2 & - & $-\mathrm{nm}$ & $-\mathrm{nm}$ & $--\mathrm{nm}$ \\
\hline 3 & - & $-\mathrm{nm}$ & $-\mathrm{nm}$ & $--\mathrm{nm}$ \\
\hline Total & 1.00 & $74.1 \mathrm{~nm}$ & $22.4 \mathrm{~nm}$ & $68.4 \mathrm{~nm}$ \\
\hline
\end{tabular}

\section{Cumulant Operations}

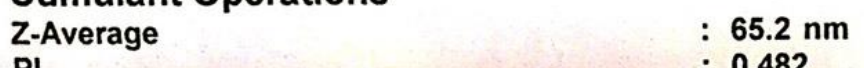

PI

: 0.482

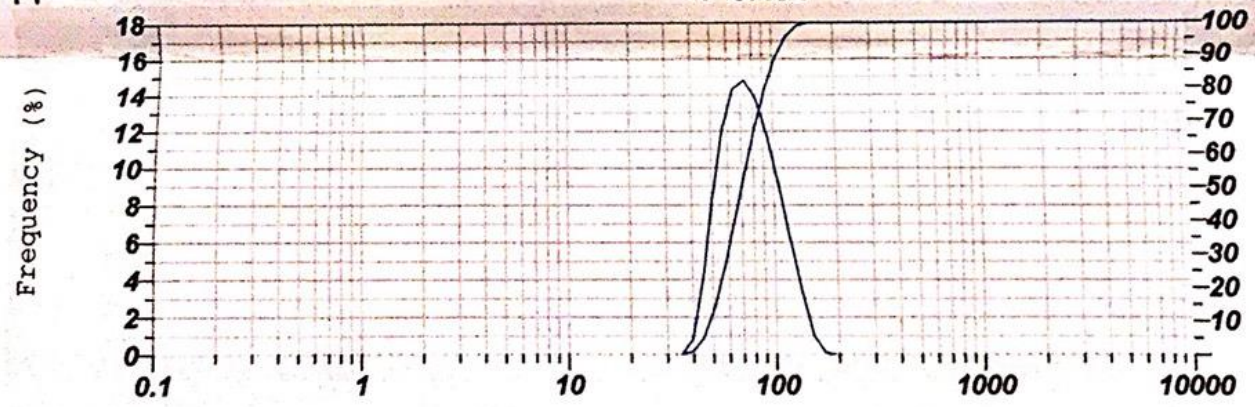

Diameter $(\mathrm{nm})$

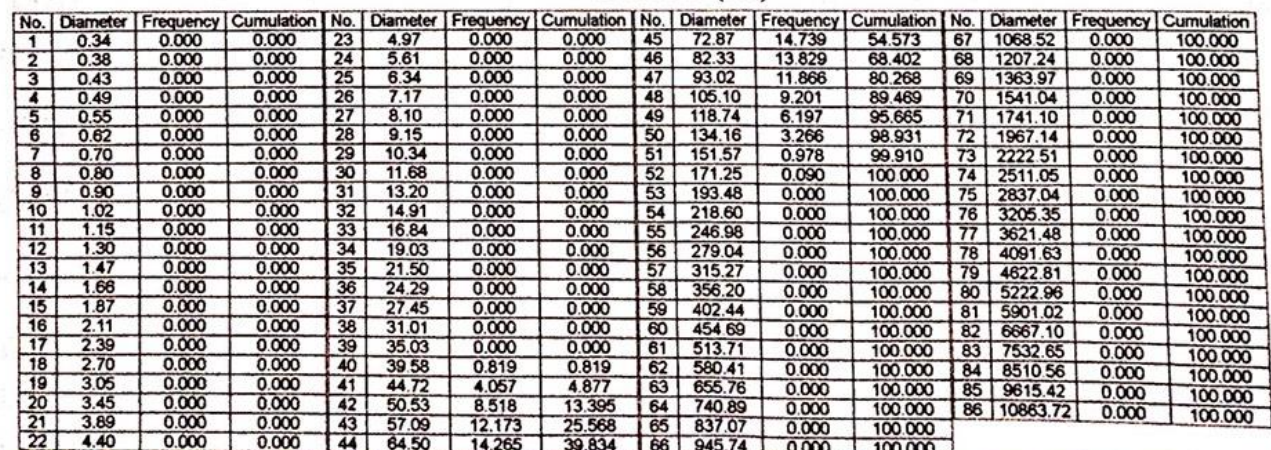

HORIEA 
Particle Size Analyzer (PSA) Replikasi 3

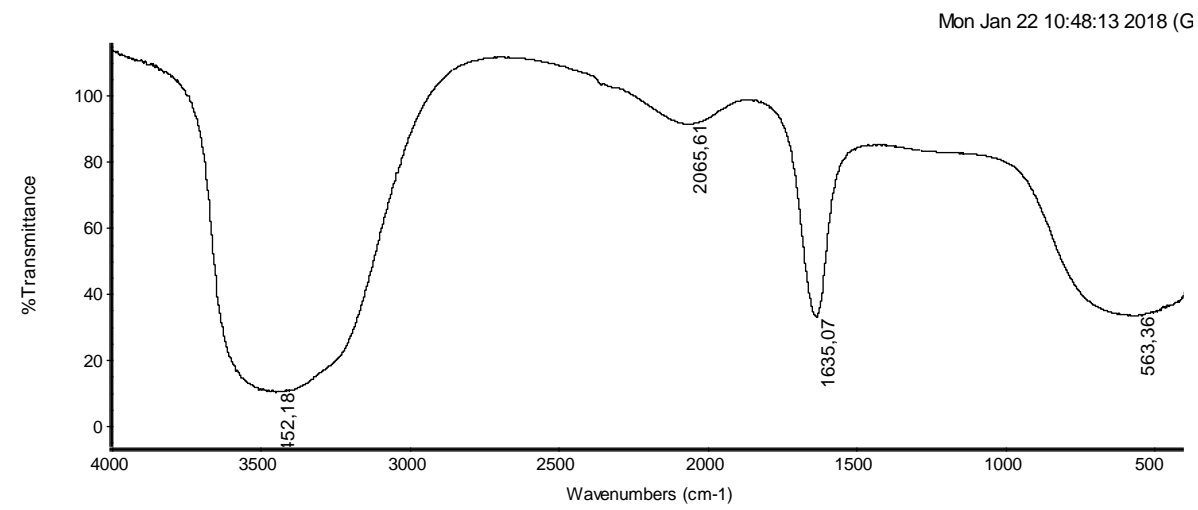

Lampiran 4 . Spektrum FTIR Ekstrak Tunggal Daun Singkong Karet.

Lampiran 5. Spektrum FTIR Nanopartikel Emas ekstrak daun singkong karet 5\% Formula 7 (ekstrak 1000 ul : $375 \mathrm{ul} \mathrm{HAuCl}_{4}$ )

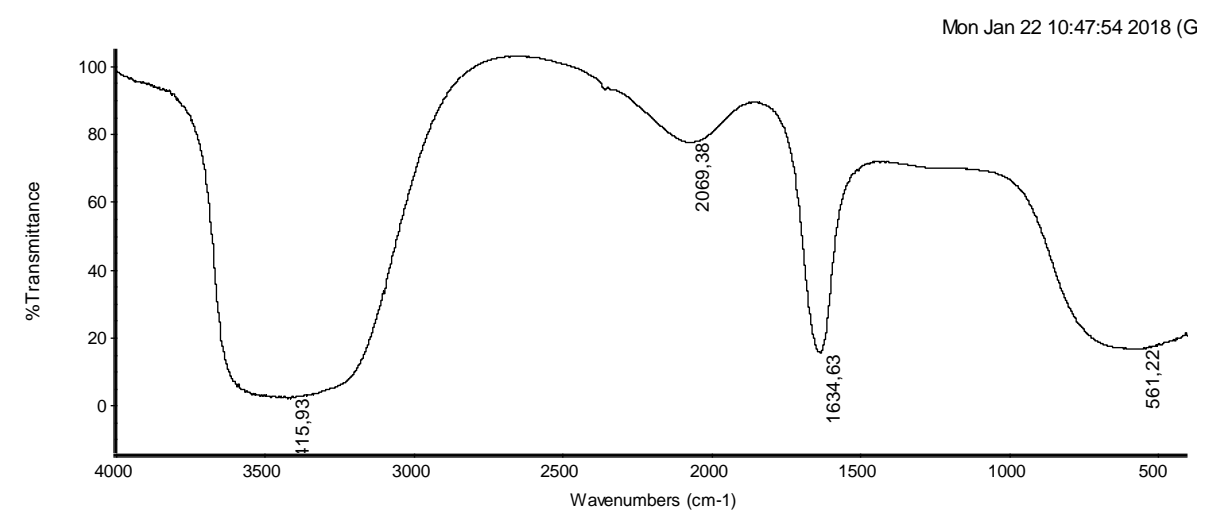

